\title{
New record and natural history notes of the Colombian endemic brown hairy dwarf porcupine, Coendou vestitus
}

\section{Nuevo registro y notas sobre historia natural del puercoespín enano pardo y peludo endémico de Colombia, Coendou vestitus}

Javier ERnesto Cortés-SuÁreZ ${ }^{1 *}$

\begin{abstract}
${ }^{1}$ Grupo de Investigación en Sistemas Socioecológicos para el Bienestar Humano, Facultad de Ciencias Básicas, Universidad del Magdalena. Calle 32 No. 22-08, 470004, Santa Marta. Magdalena, Colombia. E-mail: javi1885@gmail.com (JECS).

${ }^{*}$ Corresponding author
\end{abstract}

\begin{abstract}
The brown hairy dwarf porcupine Coendou vestitus is an endemic species to Colombia. Is one of the least studied mammals at the national level, is only known from a small area in the Eastern Cordillera, and is considered data deficient globally by the International Union for Conservation of Nature (IUCN) and threatened at the national level (Vulnerable, VU). During a bird inventory, three records of $C$. vestitus were occasionally found on the branch of a gaque and roble tree in a fragment of a secondary growth forest in the municipality of Santa Sofia, Department of Boyacá, Colombia. The new records for the species represent the seventh locality from where it is known to occur, and contribute to a better understanding of its distribution and natural history, information that ultimately is indispensable for further conservation actions.
\end{abstract}

Key words: Eastern Cordillera; geographic distribution; mammals; rodents.

El puercoespín enano pardo y peludo Coendou vestitus es una especie endémica de Colombia. Es uno de los mamíferos menos estudiados a nivel nacional, solo se conoce de una pequeña área en la Cordillera Oriental, y es considerada con datos deficientes a nivel mundial según la Union Internacional para la Conservación de la Naturaleza (UICN) y amenazada a nivel nacional (Vulnerable, VU). Durante un inventario de aves, se encontraron ocasionalmente tres registros de $C$. vestitus, en la rama de un árbol de gaque y roble en un fragmento de un bosque secundario en el municipio de Santa Sofía, departamento de Boyacá, Colombia. Los nuevos registros de la especie representan la séptima localidad desde donde se conoce su presencia y contribuyen a una mejor comprensión de su distribución e historia natural, información que en última instancia es indispensable para futuras acciones de conservación.

Palabras clave: Cordillera Oriental; distribución geográfica; mamíferos; roedores.

(c) 2020 Asociación Mexicana de Mastozoología, www.mastozoologiamexicana.org

The genus Coendou comprises 15 species (Barthelmess 2016), that range from México to Uruguay and northern Argentina. Fourteen species occur in South America, except for Coendou mexicanus. These species inhabit tropical and subtropical moist and dry forests from 0-3,500 m (Voss 2015). In Colombia, the genus Coendou its distributed along the three Andean Cordilleras and trans-Andean valleys, as well as in mountains, foothills, and adjacent lowlands from 0-3,100 m (Solari et al. 2013). According to Ramírez-Chaves et al. (2016), six species have been recognized for Colombia: C. ichillus, C. prehensilis, C. pruinosus, $C$. quichua, $C$. rufescens, and $C$. vestitus.

The brown hairy dwarf porcupine, $C$. vestitus (Thomas 1899) is a rare mammal, which is restricted to a small area of montane ecosystem from the Eastern Cordillera on Andes of central Colombia, in an elevation range from 1,250 to 2,890 m (Ramírez-Chaves et al. 2019). The species is found in Andean and sub-Andean forests which is characterized by lower montane moist forest vegetation (Emmons and Feer 1997; Voss and Da Silva 2001; Alberico and Moreno 2006; Barthelmess 2016). The International Union for Conservation of Nature (IUCN) has listed this species as "Data Deficient" (DD) given the absence of recent information on its status and ecological requirements (Weksler et al. 2016). In Colom- bia, the species has been categorized as "Vulnerable" (VU) due the reduced geographical range and habitat destruction (Alberico and Moreno 2006; Ministerio del Ambiente y Desarrollo Sostenible 2017). According to Ramírez-Chaves et al. (2019), C. vestitus is one of the least studied porcupines, and it has the most restricted distribution in America, which makes it the rarest species within the genus. Research is urgent to understand different aspects of its natural history, ecology, conservation, and distribution. To contribute to filling the lack of information for this rare species, herein, I report a new record for the species in Colombia as well as natural history observations.

On April and June 2020 during a bird inventory, three records of $C$. vestitus were occasionally found in the same place and photographed between 9:35 and 10:01 hours, in the Lower Montane Moist Forest life zone (Corpoboyacá 2015) in a farm called El Rocio located in the Vereda Sorocota, municipality of Santa Sofía, department of Boyacá $\left(5^{\circ}\right.$ $45^{\prime} 32.42^{\prime \prime} \mathrm{N},-73^{\circ} 36^{\prime} 17.97^{\prime \prime} \mathrm{W}, 2,300 \mathrm{~m}$; Figure 1). This area is located in the Magdalena Valley montane forests Ecoregion which is part of the Tropical and Subtropical Moist Broadleaf Forests Biome (Olson et al. 2001; Dinerstein et al. 2017). The specimens were recorded in a temperature transition zone in the middle of a warm and cool-season 


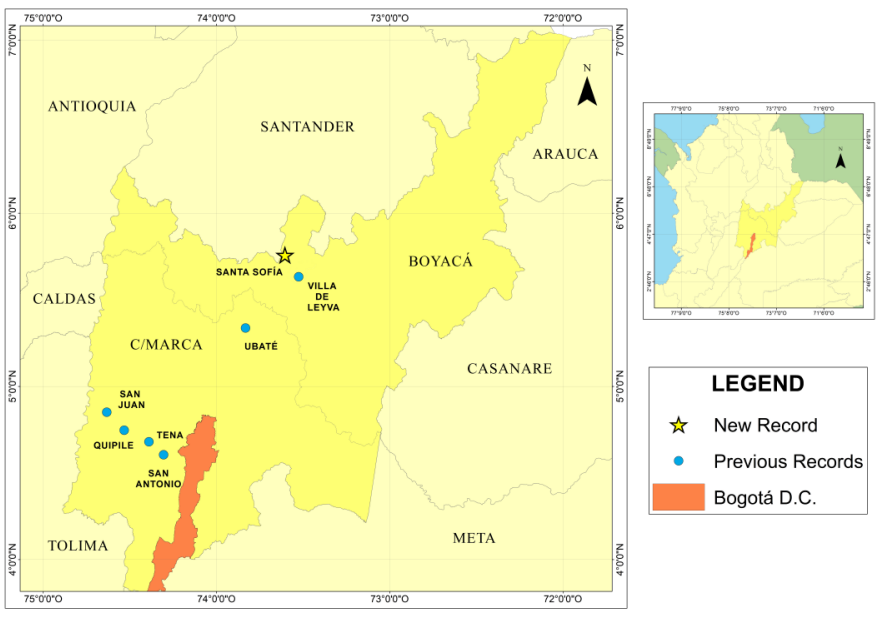

Figure 1. Coendou vestitus known distribution (blue dots) in the Eastern Cordillera of the Andes and new record (yellow star) in Boyacá department in Colombia.

(April-June), with an average between April $\left(10{ }^{\circ} \mathrm{C}-20{ }^{\circ} \mathrm{C}\right)$ and June $\left(11^{\circ} \mathrm{C}-19{ }^{\circ} \mathrm{C}\right.$; WeatherSpark 2020). Observations were also recorded during a precipitation wet season with rainfall increased in April (150-188 $\mathrm{mm}$ ) and decrease in June (104-98 mm; WeatherSpark 2020).
The specimens were not captured, the reason why it was not possible to know if the three records were only one or the same individual, and were simply identified through their external morphology following Voss (2015) and Ramírez-Chaves et al. (2019); small size (average); very short tail (about $50 \%$ of head and body length); dorsal pelage with long blackish fur that partially conceals defensive quills; bristle- quills -bicolored (whitish and dark brown or blackish distally; Figure 3a, b, c, d, e, f).

The three subadults/adults records of unknown sex were found resting in trees of secondary growth forest fragment next to an area recently affected by a fire caused in 2019 , and that is currently in a process of ecological succession (Figure 2a). The first record was found at $1.70 \mathrm{~m}$ above the ground on a branch of a gaque or cucharo (Clusia multiflora: Clusiaceae; April 8, 2020; Figure 3e, f.), and the second and third record at about $4 \mathrm{~m}$ above the ground on a branch of a roble (Quercus humboldtii: Fagaceae; June 7, 2020 and June 8, 2020; Figure $3 a, b, c, d)$. The roble tree is situated about 10 meters inside the forest from the edge outside the farm, a lotic body of water locally known as Quebrada de Piedras (Figure 2b). This section of the forest fragment is surrounded by human activities such as livestock and agriculture (Figure 2c, d).

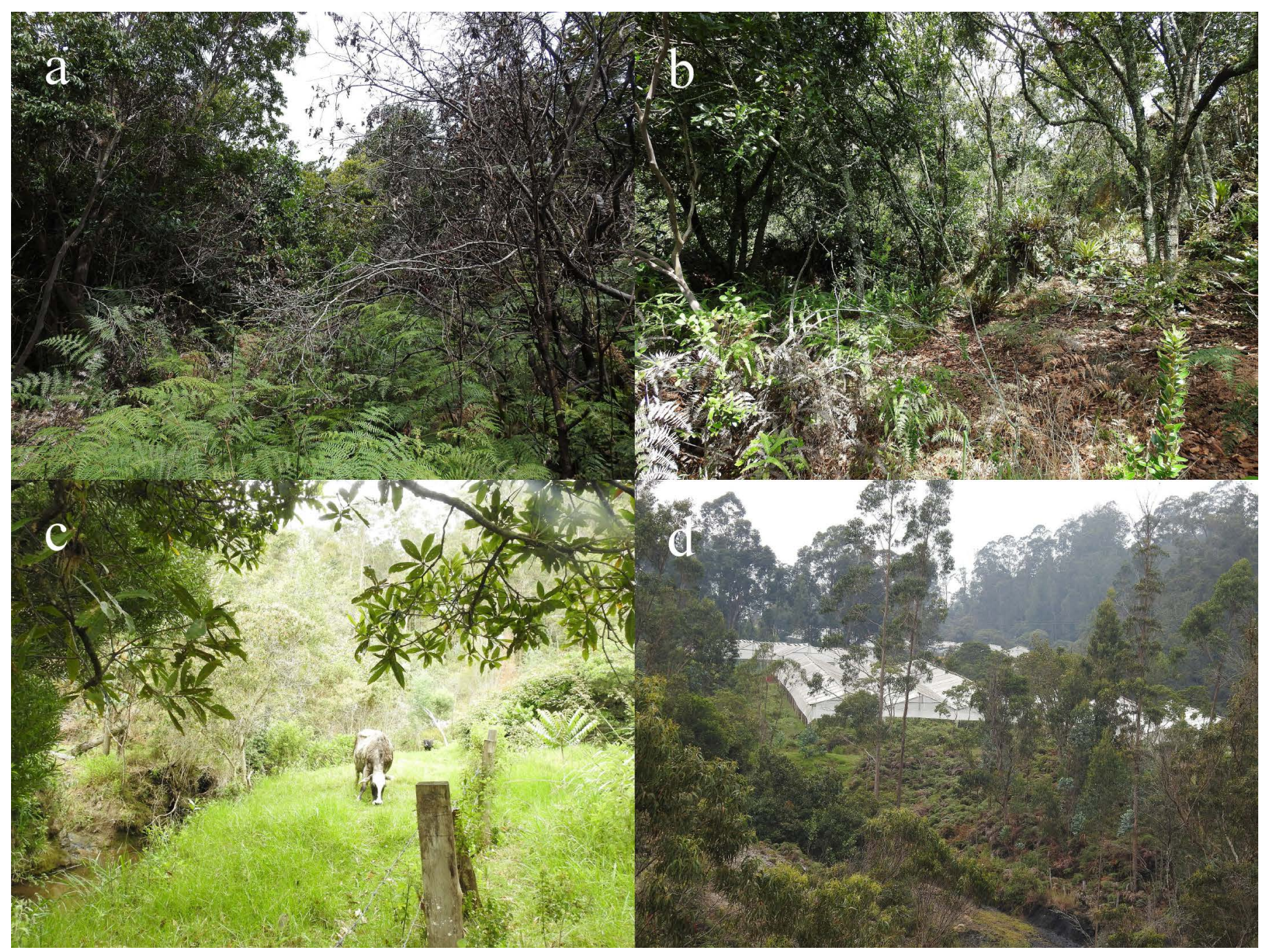

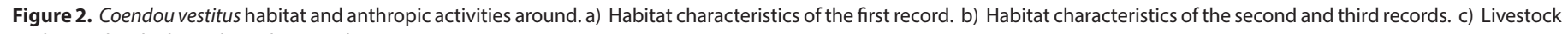
next to the Quebrada de Piedras. d) Agriculture activities. 


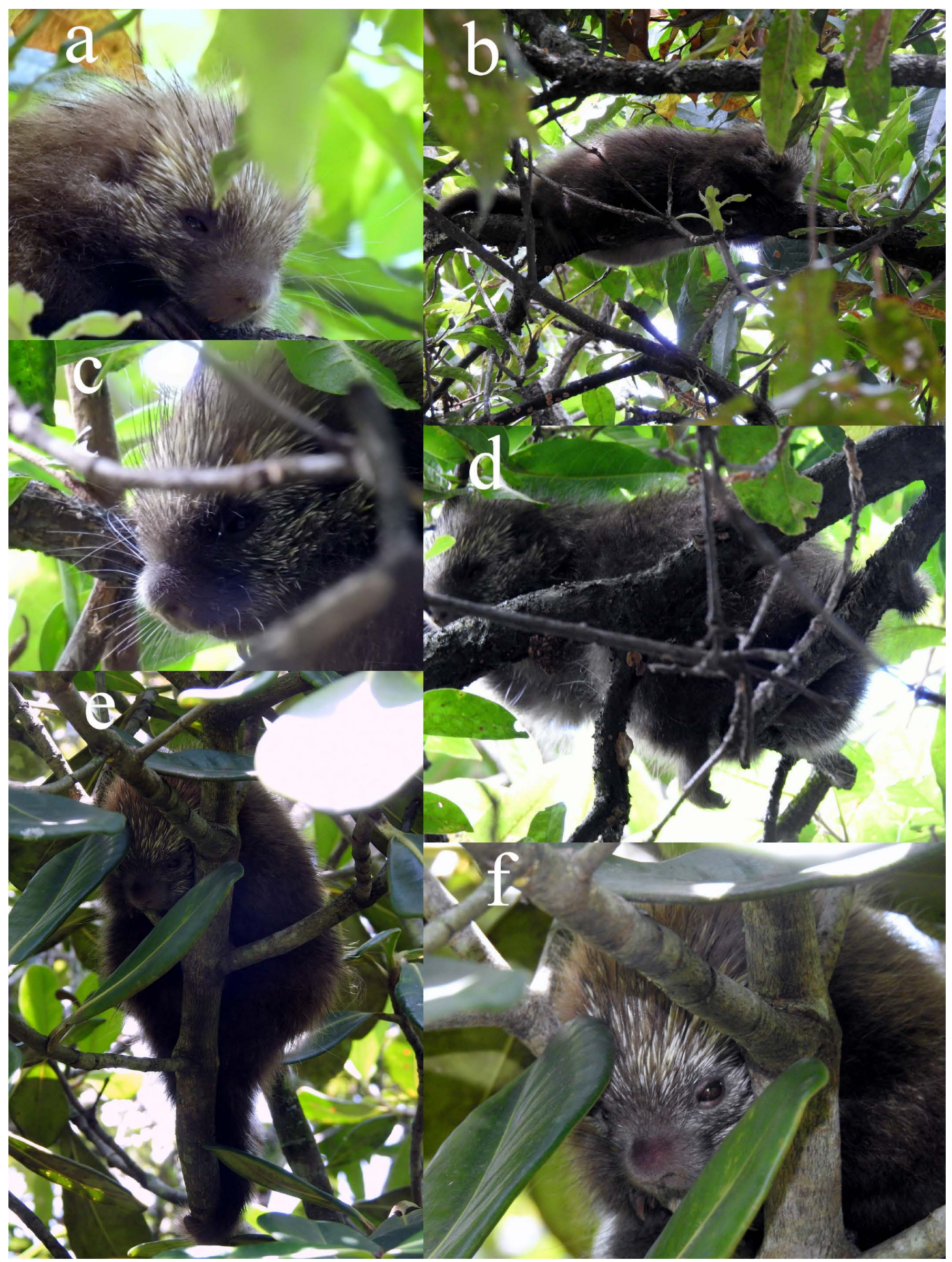

Figure 3. Photographic records from Santa Sofia, Boyacá, Colombia (first record e, f; second record c, $d$; third record a, b), showing dorsal pelage with long blackish fur that partially conceals defensive quills and relative tail size concerning head and body length $(b, c, e)$. Details of whitish basally and dark brown distally bristle quills in the face $(a, c, f)$. 
This is the first record of $C$. vestitus for the municipality of Santa Sofia in Boyacá and extends the distribution of the species $16.5 \mathrm{~km}$ in a straight line from the closest known locality at the municipality of Villa de Leyva in Boyacá (Ramírez-Chaves et al. 2019).

Coendou vestitus was recorded between a temperature transition zone (warm to cool season) during the rainy season (WeatherSpark 2020). In this life zone, the climatic conditions may be associated to exceptional topographic characteristics that facilitate the natural regeneration of forest native species due to moisture in the soil (Holdridge 1987; Kessler and Kluge 2008), as well as the occurrence of endemic species with specific habitat requirements (Kessler and Kluge 2008), such as C. vestitus. Although, its occurrence may be also related to a possible edge effect (LópezBarrera 2004), concerning its association to disturbed ecosystems such as the secondary growth forest fragment, and the probability for the species to move through other suitable habitats nearby, like biological corridors such as the Quebrada de Piedras (Concejo Municipal de Santa Sofia 2019), that allows the species to reach these or other forest fragments as climatic conditions changes and favors the availability of resources (Kessler and Kluge 2008).

According to Weksler et al. (2016), agriculture and livestock activities might be considered as possible threats for C. vestitus habitat, although this might also indicate some kind of ability for the species to adapt to disturbed Andean ecosystems; consider as the most impacted areas of Colombia due to deforestation and agriculture (Harden 2006; Rodríguez et al. 2013). The Andean Region contains more than $60 \%$ of the mammal endemic species of Colombia, but some species such as $C$. vestitus, are only known from a few localities over 1,500 m of elevation (Solari et al. 2013), which suggests further monitoring activities along the Eastern Cordillera of the Andes, in order to fill these information gaps and define other conservation actions for the species.

\section{Acknowledgements}

I thank P. Cortés-Lombana and T. Suárez-de Cortés for allowing me to enter their farm and for their hospitality. I also thank D. Amaya-Villabona for his help with the distribution map and $\mathrm{H}$. Ramírez-Chaves for his help with the identification of the second and third porcupine reported in this note.

\section{Literature cited}

Alberico, M., And J. G. Moreno. 2006. Puerco espín pardo Coendou vestitus. Pp. 293-295 in Libro Rojo de los Mamíferos de Colombia (Rodríguez-Mahecha, J. V., M. Alberico, F. Trujillo, and J. Jorgenson, eds.). Serie Libros Rojos de Especies Amenazadas de Colombia, Conservación Internacional Colombia, Ministerio de Ambiente, Vivienda y Desarrollo Territorial. Bogotá D. C., Colombia.

Barthelmess, E. L. 2016. Family Erethizontidae. Pp. 372-397 in Handbook of Mammals of the World (Wilson, D. E., T. E. Lacher Jr, and R. A. Mittermeier, eds.). Vol. 6. Lagomorphs and Rodents: Part 1, Lynx. Barcelona, Spain.
Concejo Municipal de Santa Sofía. 2019. Acuerdo No. 004 de 2019. Por medio del cual se adopta la revisión general y ajuste del Esquema de Ordenamiento Territorial del Municipio de Santa Sofía - Boyacá. Concejo Municipal de Santa Sofía. Colombia. 6 Mayo de 2019.

СовpoboyacÁ. 2015. Atlas Ambiental de Corpoboyacá. Elementos del Medio Natural. Primera Edición, Corpoboyacá. https://www.corpoboyaca.gov.co/servicios-de-informacion/ atlas-geografico-y-ambiental/. Accessed on 25 June 2020.

Dinerstein, E., D. Olson, A. Joshi, C. Vynne, N. D. Burgess, E. Wikramanayake, N. Hahn, S. Palminterl, P. Hedao, R. Noss, M. Hansen, H. Locke, E. C. Ellis, B. Jones, C.V. Barber, R. Hayes, C. Kormos, V. Martin, E. Crist, W. Sechrest, L. Price, J. E. M. Balllie, D. Weeden, K. Suckling, C. Davis, S. Nigel, R. Moore, D. Thau, T. Birch, P. Potapov, S. Turubanova, A. Tyukavina, N. D. Souza, L. Pintea, J. C. Brito, O. A. Llewellyn, A. G. Miller, A. Pataelt, S. A. Ghazanfar, J. Timberlake, H. Kloser, Y. Shennan-farpon, R. Kindt, J. B. Lilleso, P. van Breugel, L. Graudal, M. Voge, K. F. AL-ShamMARI, AND M. SALeEM. 2017. An ecoregion-based approach to protecting half the terrestrial realm. Bioscience 67:534-545.

Emmons, L. H., AND F. Feer. 1997. Neotropical rainforest mammals: A Field Guide, 2nd edition. University of Chicago Press, Chicago, U. S. A.

HARDEN, C. P. 2006. Human impacts on headwater fluvial systems in the northern and central Andes. Geomorphology 79:249-263.

HoldRIDGE, L. R. 1987. Ecología basada en zonas de vida, Tercera edición. Instituto Interamericano de Ciencias Agrícolas. San José, Costa Rica.

Kessler, M., AND J. Kluge. 2008. Diversity and endemism in tropical montane forests - from patterns to processes. Biodiversity and Ecology Series 2:35-50.

López-Barrera, F. 2004. Estructura y función en bordes de bosques. Ecosistemas 1:1-16.

Ministerio del Ambiente y Desarrollo Sostenible. 2017. Resolución No. 0192, que establece el listado de las especies silvestres amenazadas de la diversidad biológica colombiana continental y marino costera que se encuentran en el territorio nacional, y se dictan otras disposiciones. Ministerio del Ambiente y Desarrollo Sostenible. Colombia. 15 de septiembre de 2017.

Olson, D. M., E. Dinerstein, E. D. Wikramanayake, N. D. Burgess, G. V. N. Powell, E. C. UnderWood, J. A. D'Amico, I. Itoua, H. E. Strand, J. C. Morrison, C. J. Loucks, T. F Allnutt, T. H. Ricketts, Y. Kura, J. F. Lamoreux, W. W. Wettengel, P. Hedao, and K. R. KASSEM. 2001. Terrestrial ecoregions of the world: a new map of life on Earth. Bioscience 51:933-938.

Ramírez-Chaves, H. E., A. F. Suárez-Castro, D. M. Morales-Martínez, and M. C. Vallejo-Pareja. 2016. Richness and distribution of porcupines (Erethizontidae: Coendou) from Colombia. Mammalia 80:181-191.

Ramírez-Chaves, H. E., M. M. Torres-Martínez, E. A. Noguera-URbano, F. C. Passos, and J. E. Colmenares-Pinzón. 2019. State of knowledge and potential distribution of the Colombian endemic brown hairy dwarf porcupine Coendou vestitus (Rodentia). Mammalian Biology 99:1-11.

Rodriguez, N., D. Armenteras-Pascual, and J. R. Alumbreros. 2013. Land use and landcover change in the Colombian Andes: dynamics and future scenarios. Journal of Land Use Science 8:154-174. 
Solari, S., Y. Muñoz-Saba, J. Rodríguez-Mahecha, T. R. Defler, H. E. Ramirez-Chaves, and F. Trujlllo. 2013. Riqueza, Endemismo y conservación de los mamíferos de Colombia. Mastozoología Neotropical 20:301-365.

Voss, R. S. 2015. Superfamily Erethizontoidea Bonaparte, 1845. Pp. 786-805 in Mammals of South America (Patton, J. L., U. F. J. Pardiñas, and G. D. D'Elía, eds.). Volume 2. Rodents. The University of Chicago Press. Chicago, U. S. A.

Voss, R. S., AND M. N. F. DA Silva. 2001. Revisionary notes on neotropical porcupines (Rodentia, Erethizontidae). A review of the Coendou vestitus group with descriptions of two new species from Amazonia. American Museum Novitates 3351:1-36.

WeatherSpark. 2020. Temperature and precipitation for Santa Sofia. In: WeatherSpark 2020. Cedar Lake Ventures, Inc. Version 2020.1. www.weatherspark.com/. Accessed on 25 June 2020.

Weksler, M., R. P. Anderson, AND M. Gómez-Laverde. 2016. Coendou vestitus. In: IUCN 2020. The IUCN Red List of Threatened Species. Version 2016. 2. www.iucnredlist.org. Accessed on 08 April 2020.

Associated editor: José F. Moreira-Ramírez

Submitted: May 18, 2020; Reviewed: August 18, 2020.

Accepted: August 20, 2020; Published on line: August 31, 2020 